\title{
A Rare Variant in COL11A1 Is Strongly Associated with Adult Height in Chinese
}

\section{Han Population}

Changbing Shen ${ }^{\text {a,b,c,h }}$, Xiaodong Zheng ${ }^{\text {a,b,c,h }}$, Jing Gao, ${ }^{\text {d,h }}$, Caihong Zhu ${ }^{\text {a,b,c }}$, Randy Ko ${ }^{\text {e }}$,

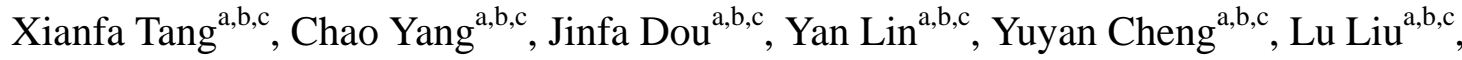
Shuangjun $\mathrm{Xu}^{\mathrm{a}, \mathrm{b}, \mathrm{c}}$,Gang Chen ${ }^{\mathrm{a}, \mathrm{b}, \mathrm{c}}$, Xianbo Zuo ${ }^{\mathrm{a}, \mathrm{b}, \mathrm{c}}$, Xianyong Yin ${ }^{\mathrm{f}}$, Liangdan Sun ${ }^{\mathrm{a}, \mathrm{b}, \mathrm{c}}$, Yong Cui ${ }^{\mathrm{g}}$, Sen Yang ${ }^{\mathrm{a}, \mathrm{b}, \mathrm{c}}$, Xuejun Zhang ${ }^{\mathrm{a}, \mathrm{b}, \mathrm{c}, \mathrm{e}, *}$, Fusheng Zhou ${ }^{\mathrm{a}, \mathrm{b}, \mathrm{c}, *}$

${ }^{a}$ Institute and Department of Dermatology, The First Affiliated Hospital, Anhui Medical University, Hefei 230032, China

${ }^{b}$ The Key Laboratory of Dermatology, Ministry of Education, Anhui Medical University, Hefei 230032, China

${ }^{c}$ Collaborative Innovation Center for Complex and Severe Dermatosis, Anhui Medical University, Hefei 230032, China

${ }^{\mathrm{d}}$ Department of Dermatology, The Second Affiliated Hospital, Anhui Medical University, Hefei 230601, China

${ }^{\mathrm{e}}$ Department of Biochemistry, University of New Mexico, Albuquerque, NM 87131, USA

${ }^{\mathrm{f}}$ Department of Genetics, and Renaissance Computing Institute, University of North Carolina at Chapel Hill, Chapel Hill, NC 27517, USA

${ }^{\mathrm{g}}$ Department of Dermatology, China-Japan Friendship Hospital, Beijing 100029, China

${ }^{\mathrm{h}}$ The first three authors contribute equally to this work.

*Corresponding authors. Tel/fax: +86 55165138576 (X. Zhang and F. Zhou) 
E-mail addresses: ayzxj@vip.sina.com (X. Zhang); biozhoufs@163.com (F. Zhou) 


\section{ABSTRACT}

Human height is a highly heritable trait in which multiple genes are involved. Recent genome-wide association studies have identified that COL11Al is an important susceptibility gene for human height. To determine whether the variants of COL11Alassociate with adult and children height, we analyzed splicing and coding single-nucleotide variants across COL11Al through exome-targeted sequencing and two validation stages with a total 20,426 Chinese Han samples. A total of 105 variants were identified by exome-targeted sequencing, of which 30 SNPs were located in coding region. The strongest association signal between Chr1_103380393 and height was $P$ _value of $4.8 \times 10^{-7}$. Chr1_103380393 also showed nominal significance in the validation stage $\left(P=1.21 \times 10^{-6}\right)$. Combined analysis of 16738 samples strengthened the original association of chr1_103380393 with adult height $\left(P_{\text {combined }}=\right.$ $3.1 \times 10^{-8}$ ), with an increased height of 0.292 sd (standard deviation) per $\mathrm{G}$ allele (95\% CI: $0.19-0.40)$. There was no evidences $(P=0.843)$ showing that chr1_103380393 altered child height in 3688 child samples. Only the group of 12-15 years showed slight significance with $P$-value of 0.0258 .This study firstly shows that genetic variants of COL11Al contribute to adult height in Chinese Han population but not to children height, which expand our knowledge of the genetic factors underlying height variation and the biological regulation of human height.

KEY WORDS: Rare variant; COL11A1; Adult height; Chinese Han population 


\section{INTRODUCTION}

Human height, a classic polygenic trait that involves multiple genetic loci, is the result of various growth and development processes and also associated with various human diseases under strong genetic influence with an estimated heritability of up to $80 \%-90 \%$ (Macgregor et al., 2006). Since 2008, multiple genome-wide association studies (GWASs) have identified about 200 susceptibility genes or loci associated with height with a genome-wide significance(Weedon et al., 2007; Kimura et al., 2008; Sanna et al., 2008; Liu et al., 2010; Perola, 2011; Hao et al., 2013; Tetens et al., 2013). Genetic variants affecting height variation might provide new insight into human growth and development, as well as the genetic architecture of common human traits and diseases (Weedon and Frayling, 2008; Wood et al., 2014).

Evidence has suggested that COL11A1 may influence human height by interacting with pathways involved in bone development (Lanktree et al., 2011). A series of studies have reported that genetic defects of COL11Al are accompanied by bone related diseases (Richards et al., 2012; Raine et al., 2013). Mutations in COL11Alcause various types of chondrodysplasias in humans, such as Stickler syndrome type II and Marshall syndrome(Annunen et al., 1999). For genetically modified COL11Al gene, limb bones of newborn cho/cho mice are wider at the metaphysics than normal bones and only about half the normal length (Li et al., 1995). Recently, GWASs revealed SNPs (rs4338381 and rs7517682) of COL11A1 that have significantly associated with height in individuals derived from European ancestry and other ethnicities (Lanktree et al., 2011; Wood et al., 2014). The GWAS 
implications couple with the established notion that coding variants profoundly influence various diseases and quantitative phenotypes, raising the assumption that coding SNPs of COL11Almay contribute to the development of human height.

Although numerous genetic loci associated with human adult height have been identified by GWASs, most of them are common variants located in the non-coding regions, emphasizing the necessity of identifying rare variants with lower frequency in exonic regions, which might reveal biological functional insights for genetic effects on height susceptibility. A recent study performed the whole-genome exome sequencing in a relatively small number of samples, and successfully unraveled the contribution of coding variants with minor allele frequency (MAF) $<5 \%$ to height variation (Du et al., 2014).In this study, we attempted to detect and verify the genetic association between susceptible coding SNPs of COL11Aland adult or children height in Chinese Han population.

\section{RESULTS}

\section{Demographic characteristics of the study subjects}

We selected the data information of 20,426 individuals from our previous study. For the discovery stage, 8190 subjects (4657 males and 3533 females) come from mid-east China, mainly Anhui, Shandong, Henan and Jiangsu provinces. In the validation stage, 8548 healthy adults (4358 males and 4190 females) were included. All the adult subjects were over 20 years old at the time of examination. In addition, 3688 children subjects, including 2377 boys and 1311 girls, were also recruited from 
Anhui province and Shanghai, under the age of 15 years old, with 53.3\% (1966/3688) younger than 3 years old. There were no significant differences of gender, height, or BMI distributions among female versus male. The characteristics of the samples were sufficient and available for analysis (All data collected are shown in Table S1).

\section{Variants of COL11A1associate with adult height}

The coding and exon-intron boundary $( \pm 50 \mathrm{bp})$ regions of COL11Alwere sequenced in 8190 adult samples. A total of 105 variants were identified, including three common variants with MAF $>5 \%$, eight rare variants with $0.5 \%<\mathrm{MAF}<5 \%$ and 94 low frequency variants with MAF $<0.5 \%$. Approximately $82.9 \%(87 / 105)$ of the variants was previously unreported in the human genetic database (dbSNP, build 130). In addition, 30 SNPs were located in coding regions, including 26 missense and 4 synonymous variants. There has not been a nonsense or frame shift variant observed in this study. (All data are shown in Table S2)

\section{Genetic association analysis in adult height}

To increase the statistical power, we mainly focused on the variants with MAF $>0.5 \%$. We first performed an association analysis for the 11 SNPs with MAF $>0.5 \%$ in 8190 adult samples. We identified three SNPs (chr1_103380393, rs992100, and rs111980222) that reached the significant threshold $4.5 \times 10^{-3}$ (multiple corrected $P=$ 0.05/11). The SNP strongest association with height was chr1_103380393 with $P$ value of $4.80 \times 10^{-7}$ (Table 1). The other two SNPs, rs992100 and rs111980222, were in strong linkage disequilibrium (LD) with chr1_103380393 $\left(r^{2}=0.809\right.$ and $r^{2}=0.541$, respectively) (Fig. 1). We thus genotyped chr1_103380393 in the validation stage (Fig. 
S1), and SNP chr1_103380393 also showed nominal significance $\left(P=1.21 \times 10^{-6}\right)$. Combined analysis of 16738 samples strengthened the original associations of chr1_103380393 with adult height $\left(P_{\text {combined }}=3.10 \times 10^{-8}\right)$, with an increased height of 0.292sd (standard deviation) per G allele (95\% CI: 0.19-0.40) (Table 1).

\section{Genetic association analysis in children height}

To determine the association between chr1_103380393and children height, we stratified the children samples $(n=3688)$ into five groups depending on the age. The results showed only $12-15$ years age group with slightly statistical significance $(P=$ 0.0258). There was no evidence $(P=0.843)$ showing that chr1_103380393 affects children height in total (Table 1).

\section{Verification of rs4338381 and rs7517682 in Chinese Han population}

Previous GWASs have identified two height-related markers rs4338381 and rs7517682 in COL11Al region in individuals of non-Asian ancestry. To assess whether the two reported SNPs are also associated with Chinese adult height, we genotyped rs4338381 and rs7517682 in the validation stage (Fig. S1). The genotype distributions and allele frequencies of chr1_103380393, rs4338381 and rs7517682 in target sequencing and validation stages are shown in Table 2. We found that SNPs rs4338381 and rs7517682 did not show strong evidence for association with adult height in our study $(P=0.45$ and 0.017 , respectively).

\section{DISCUSSION}

Bone and cartilage mostly consist of extra-cellular matrix (ECM). Collagens are 
major functional components of ECM, which perform multiple fundamental functions in human body especially in regulating bone longitudinal growth. Collagens can act as signal transducers and regulate cellular proliferation, migration, ECM adaption and degradation, with a key role in the maintenance of the physiological structure and function of the bone. The structural and functional abnormality of ECM will lead to various clinical phenotypes including fractures, lumbar disc herniation, osteoporosis and severe height related syndrome. Type XI collagen (COL11), a quantitatively minor component of ECM, is important for cartilage collagen fibril formation and ECM organization. COL11 is composed of $\alpha 1$ (XI), $\alpha 2$ (XI) and $\alpha 3$ (XI) chains, which are encoded by genes COL11A1 (1p21.1), COL11A2 (6p21.3) and COL2A1 (12q13.11-q13.2) respectively (Keene et al., 1995). Evidence suggeststhat COL11A1 influences human height by interacting with pathways involved in bone development (Li et al., 1995).

Human height is a heritable quantitative trait influenced by complex interplay between genetic variants, environmental and nutrient factors. Although the recent GWASs data enable us to identify hundreds of genetic loci that are associated with height, the identified SNPs to date only explain approximately $10 \%$ of the variation to height, indicating more susceptibility loci influencing height(Lango Allen et al., 2010). Moreover, most of the implicated SNPs are common variants with small effect size lying on intergenic and/or intronic regions, emphasizing the need to explore potentially causal elements on exonic or splicing regions that may functionally relate to human height (Perola, 2011). The COL11A1 gene have been linked with normal 
adult height in GWAS studies but the coding or causal variants have not yet been extensively studied, which might be due to small sample size or limited available sequencing data.

In this study, our primary aim is to identify the potentially causal variants in COL11Alt that affects human height. We thus evaluated the exonic and intragenic variants of COL11Alin 8190 Chinese adults by using exome sequencing, and identified three SNPs (chr1_103380393, rs992100, and rs111980222) that are significantly associated with adult height. The most significant association signal of chr1_103380393 was further confirmed in additional 8548 adult subjects. The variant chr1_103380393 is located between the 50th and 51st exons of COL11Al gene, suggesting intragenic noncoding polymorphism might execute an important role in regulating gene function, and further supporting the notion that Type XI collagen is critical for human height development. After retrieving the public ChIP-seq data of the chr1_103380393 region from GM12878 cell line, we found that the region is not enriched for chromatin structure marked by H3K4me3, H3K27Ac and DnaseI hypersensitivity sites (DHS) (Fig. S2), indicating that this variation may not be directly involved in active regulation of this gene. The regulatory function of this variation may be through some undetermined mechanism. COL11Al encodes one of the two $\alpha$ chains of type XI collagen, a minor fibrillar collagen, which is essential for skeletal morphogenesis ( $\mathrm{Li}$ et al., 1995). Type XI collagen is a heterotrimer but the third $\alpha$ chain is a post-translationally modified $\alpha 1$ type II chain. Mutations in COL11A1 are associated with type II Stickler syndrome and Marshall syndrome 
(Annunen et al., 1999). Type II Stickler syndrome is usually a dominant disorder due to mutations in the collagen gene COL11A1, and is characterized by unusually severe/profound hearing loss and a series of damage in eye, bone and joint, and blood vessels (Snead and Yates, 1999). We proposed that COL11Al might be a key regulatory gene affecting the bone growth, and acts as an important factor inhuman height.

We firstly identified that chr1_103380393 in COL11A1 was associated with adult height in the two-stage study, but this relationship was not associated with children height. However, we discovered the group (12-15 years) with slightly statistical significance by stratified analysis. There was no evidence showing that the chr1_103380393 altered children height in total from 0 to 15 years old. Due to the shortage of children samples in this experiment, we do not know whether there is a relationship between chr1_103380393 and children height among 15- to 18-year- old group. Further studies need much more samples to identify the association between chr1_103380393 and children height. Despite the association with height for individuals of European and Africa ancestry (Lanktree et al., 2011; Wood et al., 2014), the reported top hits mapped to this region (rs4338381 and rs7517682) did not show strong evidence for association with adult height in our validation samples. The reason for this phenomenon might be due to the limitation of the modest sample size in our validation stage, which probably influences the result of the association test with height. Furthermore, the MAF for both SNPs varies widely across Chinese (CHB), European (CEU) and Africa (RYI) populations in the Hapmap project 
(www.hapmap.org). For example, the G allele of rs4338381 is substantially lower in CHB when compared with CEU and RYI populations $(10.5 \%, 38.9 \%$ and $40.3 \%$ for CHB, CEU and RYI respectively). There might be different peak signal associated with height in different ethnicity, as indicated in current study. We observed weak LD among chr1_103380393, rs992100 and rs111980222, suggesting the newly identified SNP represents a new signal and might not be covered by previous hits. Since the different distributions of height between populations suggest different genetic backgrounds, analysis in different populations would be useful.

In summary, our study confirmed that COL11Alis acandidate gene associated with adult height. Further, we firstly identified an intragenic variant chr1_103380393 in COL11A1 contributing to adult height in Chinese Han population. Our results extend our knowledge of the genetic factors underlying height variation and the biological regulation of human height, which will help to identify the true causative variants and provide a better understanding of the mechanisms underlying human growth and development in the future. 


\section{MATERIALS AND METHODS}

\section{Study subjects}

All the subjects were enrolled for this study from Institute of Dermatology, Anhui Medical University, China. This institute mainly focuses on genetic research of common dermatosis, such as psoriasis, atopic dermatitis, vitiligo, systemic lupus erythematosus and leprosy. Up to date, more than 100,000 persons completed informed consent and accepted the survey and clinical examinations. There is no reported correlation between height and above dermatosis, which allows us to carry out height genetic research using dataset of these diseases. In total, 20,426 individuals were collected in this study. All samples with medical conditions affecting adult height, such as dwarfism, gigantism and acromegaly, were excluded. All the participants provided written informed consent. This study was approved by Ethic Committee of Faculty of Medicine at Anhui Medical University.

\section{Target capture and exome sequencing}

Our group performed target sequencing for 1364 genes, including COL11A1, in 20005 samples with $64 \times$ average coverage for the target regions, and the method for targeting, sequencing, alignment, variant calling and annotation have been described

previously (Tang et al. 2014). In brief, the selected target exonic regions were enriched to construct a SeqCapEZ library by RocheeNibleGen. Exome sequencing was performed by Hiseq2000 platform and generated 90-bp paired end reads. Raw sequencing data were aligned to NCBI human genome reference assembly (build 36.3) using BWA (Burrows-Wheeler Aligner) and recalibrated by TableRecalibration in 
Genome Analysis Toolkit (GATK v1.6). Genotype information was called by SOAsnp (v1.05) in targeted and flanking 50-bp regions for each sample. The software ANNOVAR was used to categorize SNPs into different groups based on their genic location and expected function on encoded gene products. The SNPs were also classified into "known" and "unknown" categories according to whether they present in dbSNP (version 135). The quality control for SNPs or samples also includes: call rate $\geq 90 \%$ for each probes on all samples, samples with individual call rate $\geq 90 \%$, and Hardy-Weinberg test $P$-value $\geq 1.0 \times 10^{-4}$. In order to explore what kind of variants of COL11Alcontributes to adult height, we extracted the target sequencing data of our psoriasis project, including 8190 adult subjects, and tested whether these variants are associated with height.

\section{SNPs selection and genotyping}

The SNPs showing statistical significance after adjusting for multiple comparisons in the discovery stage were selected for further validation. There were 11 SNPs with MAF>0.5\% and three SNPs (chr1_103380393, rs992100 and rs111980222) reached the statistically significant threshold $4.5 \times 10^{-3}(0.05 / 11)$. For SNPs located in blocks with strong $\operatorname{LD}\left(r^{2}>0.8\right)$, the one with the most significant signal entered into the validation stage. Genotyping of chr1_103152981was conducted in additional 8548 adults and 3688 children. We also genotyped the two reported SNPs rs4338381 and rs7517682 (Lanktree et al. 2011; Wood et al. 2014) in the validation stage of 8548 adults. Genotyping for the validation stage was conducted using MALDI-TOF (matrix-assisted laser desorption time of flight) mass spectrometry (Sequenom, USA). 
A total of 20ng genomic DNA was used for PCR amplification, and then products were treated by shrimp alkaline phosphatase (SAP) and single base extension reaction. After cleaning with resin, nanoliter volumes of samples were transferred to Spectrochip. Genotype raw data preparation and cluster visualization were performed by Typer 4.1 Analyzer software.

\section{Statistics analysis}

The Hardy-Weinberg equilibrium (HWE) was calculated by using Peason's $\chi^{2}$ test to determine whether individual variations were in HWE at each locus in the cohort. In the association analysis, linear regression and additive genetic model were applied for genetic association test including age and gender as covariates. All the association tests were done with Plink 1.06. Linear regression coefficients and standard error of mean (s.e.m) were used to measure the strength of the association. To avoid false-positive findings due to multiple comparisons, we applied the stringent Bonfferoni correction method that can robustly control the false discovery rate. Association analysis in replication stage was performed and meta-analysis of the two stages was further proceeded by GWAS meta-analysis (GWA-MA) using an inverse-variance weighted meta-analysis on the regression coefficients. The structure of the LD block was examined by Haploview 3.02. $P_{\text {Bonfferoni }}<0.05$ was considered to be significant. 


\section{ACKNOWLEDGMENTS}

This work was supported by the grant from the Youth National Science Foundation of China (No. 31100908). We acknowledge the individuals who participated in this project and their families. We also appreciate the help from Tamilselvi Elango for collaborating with us in revising this manuscript.

\section{FIGURE TITLE}

Fig. 1. Linkage disequilibrium analysis of variants of COL11A1 with MAF $>0.5 \%$ 


\section{REFERENCES}

Annunen, S., Korkko, J., Czarny, M., Warman, M.L., Brunner, H.G., Kaariainen, H., Mulliken, J.B., Tranebjaerg, L., Brooks, D.G., Cox, G.F., Cruysberg, J.R., Curtis, M.A., Davenport, S.L., Friedrich, C.A., Kaitila, I., Krawczynski, M.R., Latos-Bielenska, A., Mukai, S., Olsen, B.R., Shinno, N., Somer, M., Vikkula, M., Zlotogora, J., Prockop, D.J., Ala-Kokko, L., 1999. Splicing mutations of 54-bp exons in the COL11A1 gene cause Marshall syndrome, but other mutations cause overlapping Marshall/Stickler phenotypes. Am. J. Hum. Genet. 65, 974-983.

Du, M., Auer, P.L., Jiao, S., Haessler, J., Altshuler, D., Boerwinkle, E., Carlson, C.S., Carty, C.L., Chen, Y.D., Curtis, K., Franceschini, N., Hsu, L., Jackson, R., Lange, L.A., Lettre, G., Monda, K.L., Nickerson, D.A., Reiner, A.P., Rich, S.S., Rosse, S.A., Rotter, J.I., Willer, C.J., Wilson, J.G., North, K., Kooperberg, C., Heard-Costa, N., Peters, U., 2014. Whole-exome imputation of sequence variants identified two novel alleles associated with adult body height in African Americans. Hum. Mol. Genet. 23, 6607-6615.

Hao, Y., Liu, X., Lu, X., Yang, X., Wang, L., Chen, S., Li, H., Li, J., Cao, J., Chen, J., Li, Y., Zhao, L., Shi, Y., Shen, C., Yan, W., He, J., Huang, J., Gu, D., 2013. Genome-wide association study in Han Chinese identifies three novel loci for human height. Hum. Genet. 132, 681-689.

Keene, D.R., Oxford, J.T., Morris, N.P., 1995. Ultrastructural localization of collagen types II, IX, and $\mathrm{XI}$ in the growth plate of human rib and fetal bovine epiphyseal cartilage: type XI collagen is restricted to thin fibrils. J. Histochem. Cytochem. 43, 967-979.

Kimura, T., Kobayashi, T., Munkhbat, B., Oyungerel, G., Bilegtsaikhan, T., Anar, D., Jambaldorj, J., Munkhsaikhan, S., Munkhtuvshin, N., Hayashi, H., Oka, A., Inoue, I., Inoko, H., 2008. Genome-wide association analysis with selective genotyping identifies candidate loci for adult height at 8q21.13 and 15q22.33-q23 in Mongolians. Hum. Genet., 123, 655-660.

Lango Allen, H., Estrada, K., Lettre, G., Berndt, S.I., Weedon, M.N., Rivadeneira, F., Willer, C.J., Jackson, A.U., Vedantam, S., Raychaudhuri, S., Ferreira, T., Wood, A.R., Weyant, R.J., Segre, A.V., Speliotes, E.K., Wheeler, E., Soranzo, N., Park, J.H., Yang, J., Gudbjartsson, D., Heard-Costa, N.L., Randall, J.C., Qi, L., Vernon Smith, A., Magi, R., Pastinen, T., Liang, L., Heid, I.M., Luan, J., Thorleifsson, G., Winkler, T.W., Goddard, M.E., Sin Lo, K., Palmer, C., Workalemahu, T., Aulchenko, Y.S., Johansson, A., Zillikens, M.C., Feitosa, M.F., Esko, T., Johnson, T., Ketkar, S., Kraft, P., Mangino, M., Prokopenko, I., Absher, D., Albrecht, E., Ernst, F., Glazer, N.L., Hayward, C., Hottenga, J.J., Jacobs, K.B., Knowles, J.W., Kutalik, Z., Monda, K.L., Polasek, O., Preuss, M., Rayner, N.W., Robertson, N.R., Steinthorsdottir, V., Tyrer, J.P., Voight, B.F., Wiklund, F., Xu, J., Zhao, J.H., Nyholt, D.R., Pellikka, N., Perola, M., Perry, J.R., Surakka, I., Tammesoo, M.L., Altmaier, E.L., Amin, N., Aspelund, T., Bhangale, T., Boucher, G., Chasman, D.I., Chen, C., Coin, L., Cooper, M.N., Dixon, A.L., Gibson, Q., Grundberg, E., Hao, K., Juhani Junttila, M., Kaplan, L.M., Kettunen, J., Konig, I.R., Kwan, T., Lawrence, R.W., Levinson, D.F., Lorentzon, M., McKnight, B., Morris, A.P., Muller, M., Suh Ngwa, J., Purcell, S., Rafelt, S., Salem, R.M., Salvi, E., Sanna, S., Shi, J., Sovio, U., Thompson, J.R., Turchin, M.C., Vandenput, L., Verlaan, D.J., Vitart, V., White, C.C., Ziegler, A., Almgren, P., Balmforth, A.J., Campbell, H., Citterio, L., De Grandi, A., Dominiczak, A., Duan, J., Elliott, P., Elosua, R., Eriksson, J.G., Freimer, N.B., Geus, E.J., Glorioso, N., Haiqing, S., Hartikainen, A.L., Havulinna, A.S., Hicks, A.A., Hui, J., Igl, W., Illig, T., Jula, A., Kajantie, E., Kilpelainen, T.O., Koiranen, M., Kolcic, I., Koskinen, S., Kovacs, P., Laitinen, J., Liu, J., Lokki, M.L., 
Marusic, A., Maschio, A., Meitinger, T., Mulas, A., Pare, G., Parker, A.N., Peden, J.F., Petersmann, A., Pichler, I., Pietilainen, K.H., Pouta, A., Ridderstrale, M., Rotter, J.I., Sambrook, J.G., Sanders, A.R., Schmidt, C.O., Sinisalo, J., Smit, J.H., Stringham, H.M., Bragi Walters, G., Widen, E., Wild, S.H., Willemsen, G., Zagato, L., Zgaga, L., Zitting, P., Alavere, H., Farrall, M., McArdle, W.L., Nelis, M., Peters, M.J., Ripatti, S., van Meurs, J.B., Aben, K.K., Ardlie, K.G., Beckmann, J.S., Beilby, J.P., Bergman, R.N., Bergmann, S., Collins, F.S., Cusi, D., den Heijer, M., Eiriksdottir, G., Gejman, P.V., Hall, A.S., Hamsten, A., Huikuri, H.V., Iribarren, C., Kahonen, M., Kaprio, J., Kathiresan, S., Kiemeney, L., Kocher, T., Launer, L.J., Lehtimaki, T., Melander, O., Mosley, T.H., Jr., Musk, A.W., Nieminen, M.S., O'Donnell, C.J., Ohlsson, C., Oostra, B., Palmer, L.J., Raitakari, O., Ridker, P.M., Rioux, J.D., Rissanen, A., Rivolta, C., Schunkert, H., Shuldiner, A.R., Siscovick, D.S., Stumvoll, M., Tonjes, A., Tuomilehto, J., van Ommen, G.J., Viikari, J., Heath, A.C., Martin, N.G., Montgomery, G.W., Province, M.A., Kayser, M., Arnold, A.M., Atwood, L.D., Boerwinkle, E., Chanock, S.J., Deloukas, P., Gieger, C., Gronberg, H., Hall, P., Hattersley, A.T., Hengstenberg, C., Hoffman, W., Lathrop, G.M., Salomaa, V., Schreiber, S., Uda, M., Waterworth, D., Wright, A.F., Assimes, T.L., Barroso, I., Hofman, A., Mohlke, K.L., Boomsma, D.I., Caulfield, M.J., Cupples, L.A., Erdmann, J., Fox, C.S., Gudnason, V., Gyllensten, U., Harris, T.B., Hayes, R.B., Jarvelin, M.R., Mooser, V., Munroe, P.B., Ouwehand, W.H., Penninx, B.W., Pramstaller, P.P., Quertermous, T., Rudan, I., Samani, N.J., Spector, T.D., Volzke, H., Watkins, H., Wilson, J.F., Groop, L.C., Haritunians, T., Hu, F.B., Kaplan, R.C., Metspalu, A., North, K.E., Schlessinger, D., Wareham, N.J., Hunter, D.J., O'Connell, J.R., Strachan, D.P., Wichmann, H.E., Borecki, I.B., van Duijn, C.M., Schadt, E.E., Thorsteinsdottir, U., Peltonen, L., Uitterlinden, A.G., Visscher, P.M., Chatterjee, N., Loos, R.J., Boehnke, M., McCarthy, M.I., Ingelsson, E., Lindgren, C.M., Abecasis, G.R., Stefansson, K., Frayling, T.M., Hirschhorn, J.N., 2010. Hundreds of variants clustered in genomic loci and biological pathways affect human height. Nature 467, 832-838.

Lanktree, M.B., Guo, Y., Murtaza, M., Glessner, J.T., Bailey, S.D., Onland-Moret, N.C., Lettre, G., Ongen, H., Rajagopalan, R., Johnson, T., Shen, H., Nelson, C.P., Klopp, N., Baumert, J., Padmanabhan, S., Pankratz, N., Pankow, J.S., Shah, S., Taylor, K., Barnard, J., Peters, B.J., Maloney, C.M., Lobmeyer, M.T., Stanton, A., Zafarmand, M.H., Romaine, S.P., Mehta, A., van Iperen, E.P., Gong, Y., Price, T.S., Smith, E.N., Kim, C.E., Li, Y.R., Asselbergs, F.W., Atwood, L.D., Bailey, K.M., Bhatt, D., Bauer, F., Behr, E.R., Bhangale, T., Boer, J.M., Boehm, B.O., Bradfield, J.P., Brown, M., Braund, P.S., Burton, P.R., Carty, C., Chandrupatla, H.R., Chen, W., Connell, J., Dalgeorgou, C., Boer, A., Drenos, F., Elbers, C.C., Fang, J.C., Fox, C.S., Frackelton, E.C., Fuchs, B., Furlong, C.E., Gibson, Q., Gieger, C., Goel, A., Grobbee, D.E., Hastie, C., Howard, P.J., Huang, G.H., Johnson, W.C., Li, Q., Kleber, M.E., Klein, B.E., Klein, R., Kooperberg, C., Ky, B., Lacroix, A., Lanken, P., Lathrop, M., Li, M., Marshall, V., Melander, O., Mentch, F.D., Meyer, N.J., Monda, K.L., Montpetit, A., Murugesan, G., Nakayama, K., Nondahl, D., Onipinla, A., Rafelt, S., Newhouse, S.J., Otieno, F.G., Patel, S.R., Putt, M.E., Rodriguez, S., Safa, R.N., Sawyer, D.B., Schreiner, P.J., Simpson, C., Sivapalaratnam, S., Srinivasan, S.R., Suver, C., Swergold, G., Sweitzer, N.K., Thomas, K.A., Thorand, B., Timpson, N.J., Tischfield, S., Tobin, M., Tomaszewski, M., Verschuren, W.M., Wallace, C., Winkelmann, B., Zhang, H., Zheng, D., Zhang, L., Zmuda, J.M., Clarke, R., Balmforth, A.J., Danesh, J., Day, I.N., Schork, N.J., de Bakker, P.I., Delles, C., Duggan, D., 
Hingorani, A.D., Hirschhorn, J.N., Hofker, M.H., Humphries, S.E., Kivimaki, M., Lawlor, D.A., Kottke-Marchant, K., Mega, J.L., Mitchell, B.D., Morrow, D.A., Palmen, J., Redline, S., Shields, D.C., Shuldiner, A.R., Sleiman, P.M., Smith, G.D., Farrall, M., Jamshidi, Y., Christiani, D.C., Casas, J.P., Hall, A.S., Doevendans, P.A., Christie, J.D., Berenson, G.S., Murray, S.S., Illig, T., Dorn, G.W., 2nd, Cappola, T.P., Boerwinkle, E., Sever, P., Rader, D.J., Reilly, M.P., Caulfield, M., Talmud, P.J., Topol, E., Engert, J.C., Wang, K., Dominiczak, A., Hamsten, A., Curtis, S.P., Silverstein, R.L., Lange, L.A., Sabatine, M.S., Trip, M., Saleheen, D., Peden, J.F., Cruickshanks, K.J., Marz, W., O'Connell, J.R., Klungel, O.H., Wijmenga, C., Maitland-van der Zee, A.H., Schadt, E.E., Johnson, J.A., Jarvik, G.P., Papanicolaou, G.J., Grant, S.F., Munroe, P.B., North, K.E., Samani, N.J., Koenig, W., Gaunt, T.R., Anand, S.S., van der Schouw, Y.T., Soranzo, N., Fitzgerald, G.A., Reiner, A., Hegele, R.A., Hakonarson, H., Keating, B.J., 2011. Meta-analysis of dense genecentric association studies reveals common and uncommon variants associated with height. Am. J. Hum. Genet. 88, 6-18.

Li, Y., Lacerda, D.A., Warman, M.L., Beier, D.R., Yoshioka, H., Ninomiya, Y., Oxford, J.T., Morris, N.P., Andrikopoulos, K., Ramirez, F., Wardell, B.B., Lifferth, G.D., Teuscher, C., Woodward, S.R., Taylor, B.A., Seegmiller, R.E., Olsen, B.R, 1995. A fibrillar collagen gene, Colllal, is essential for skeletal morphogenesis. Cell 80, 423-430.

Liu, J.Z., Medland, S.E., Wright, M.J., Henders, A.K., Heath, A.C., Madden, P.A., Duncan, A., Montgomery, G.W., Martin, N.G., McRae, A.F., 2010. Genome-wide association study of height and body mass index in Australian twin families. Twin Res. Hum. Genet. 13,179-193.

Macgregor, S., Cornes, B.K., Martin, N.G., Visscher, P.M., 2006. Bias, precision and heritability of self-reported and clinically measured height in Australian twins. Hum. Genet. 120, 571-580.

Perola, M., 2011. Genome-wide association approaches for identifying loci for human height genes. Best Pract. Res. Clin. Endocrinol. Metab. 25,19-23.

Raine, E.V., Dodd, A.W., Reynard, L.N., Loughlin, J., 2013. Allelic expression analysis of the osteoarthritis susceptibility gene COL11A1 in human joint tissues. BMC Musculoskelet. Disord. 14, 1471-2474.

Richards, A.J., McNinch, A., Whittaker, J., Treacy, B., Oakhill, K., Poulson, A., Snead, M.P., 2012. Splicing analysis of unclassified variants in COL2A1 and COL11A1 identifies deep intronic pathogenic mutations. Eur. J. Hum. Genet., 20, 552-558.

Sanna, S., Jackson, A.U., Nagaraja, R., Willer, C.J., Chen, W.M., Bonnycastle, L.L., Shen, H., Timpson, N., Lettre, G., Usala, G., Chines, P.S., Stringham, H.M., Scott, L.J., Dei, M., Lai, S., Albai, G., Crisponi, L., Naitza, S., Doheny, K.F., Pugh, E.W., Ben-Shlomo, Y., Ebrahim, S., Lawlor, D.A., Bergman, R.N., Watanabe, R.M., Uda, M., Tuomilehto, J., Coresh, J., Hirschhorn, J.N., Shuldiner, A.R., Schlessinger, D., Collins, F.S., Davey Smith, G., Boerwinkle, E., Cao, A., Boehnke, M., Abecasis, G.R., Mohlke, K.L., 2008. Common variants in the GDF5-UQCC region are associated with variation in human height. Nat. Genet. 40,198-203.

Snead, M.P., Yates, J.R., 1999. Clinical and molecular genetics of Stickler syndrome. J. Med. Genet. 36 , 353-359.

Tang, H., Jin, X., Li, Y., Jiang, H., Tang, X., Yang, X., Cheng, H., Qiu, Y., Chen, G., Mei, J., Zhou, F., Wu, R., Zuo, X., Zhang, Y., Zheng, X., Cai, Q., Yin, X., Quan, C., Shao, H., Cui, Y., Tian, F., Zhao, X., Liu, H., Xiao, F., Xu, F., Han, J., Shi, D., Zhang, A., Zhou, C., Li, Q., Fan, X., Lin, L., Tian, H., Wang, Z., Fu, H., Wang, F., Yang, B., Huang, S., Liang, B., Xie, X., Ren, Y., Gu, Q., Wen, G., Sun, Y., Wu, X., Dang, L., Xia, M., Shan, J., Li, T., Yang, L., Zhang, X., He, C., 
Xu, A., Wei, L., Gao, X., Xu, J., Zhang, F., Zhang, J., Sun, L., Liu, J., Chen, R., Yang, S., Wang, J., 2014. A large-scale screen for coding variants predisposing to psoriasis. Nat. Genet. $46,45-50$.

Tetens, J., Widmann, P., Kuhn, C., Thaller, G., 2013. A genome-wide association study indicates LCORL/NCAPG as a candidate locus for withers height in German Warmblood horses. Anim. Genet. 44, 467-471.

Weedon, M.N., Frayling, T.M., 2008. Reaching new heights: insights into the genetics of human stature. Trends Genet. 24, 595-603.

Weedon, M.N., Lettre, G., Freathy, R.M., Lindgren, C.M., Voight, B.F., Perry, J.R., Elliott, K.S., Hackett, R., Guiducci, C., Shields, B., Zeggini, E., Lango, H., Lyssenko, V., Timpson, N.J., Burtt, N.P., Rayner, N.W., Saxena, R., Ardlie, K., Tobias, J.H., Ness, A.R., Ring, S.M., Palmer, C.N., Morris, A.D., Peltonen, L., Salomaa, V., Davey Smith, G., Groop, L.C., Hattersley, A.T., McCarthy, M.I., Hirschhorn, J.N., Frayling, T.M., 2007. A common variant of HMGA2 is associated with adult and childhood height in the general population. Nat. Genet. 39, 1245-1250.

Wood, A.R., Esko, T., Yang, J., Vedantam, S., Pers, T.H., Gustafsson, S., Chu, A.Y., Estrada, K., Luan, J., Kutalik, Z., Amin, N., Buchkovich, M.L., Croteau-Chonka, D.C., Day, F.R., Duan, Y., Fall, T., Fehrmann, R., Ferreira, T., Jackson, A.U., Karjalainen, J., Lo, K.S., Locke, A.E., Magi, R., Mihailov, E., Porcu, E., Randall, J.C., Scherag, A., Vinkhuyzen, A.A., Westra, H.J., Winkler, T.W., Workalemahu, T., Zhao, J.H., Absher, D., Albrecht, E., Anderson, D., Baron, J., Beekman, M., Demirkan, A., Ehret, G.B., Feenstra, B., Feitosa, M.F., Fischer, K., Fraser, R.M., Goel, A., Gong, J., Justice, A.E., Kanoni, S., Kleber, M.E., Kristiansson, K., Lim, U., Lotay, V., Lui, J.C., Mangino, M., Mateo Leach, I., Medina-Gomez, C., Nalls, M.A., Nyholt, D.R., Palmer, C.D., Pasko, D., Pechlivanis, S., Prokopenko, I., Ried, J.S., Ripke, S., Shungin, D., Stancakova, A., Strawbridge, R.J., Sung, Y.J., Tanaka, T., Teumer, A., Trompet, S., van der Laan, S.W., van Setten, J., Van Vliet-Ostaptchouk, J.V., Wang, Z., Yengo, L., Zhang, W., Afzal, U., Arnlov, J., Arscott, G.M., Bandinelli, S., Barrett, A., Bellis, C., Bennett, A.J., Berne, C., Bluher, M., Bolton, J.L., Bottcher, Y., Boyd, H.A., Bruinenberg, M., Buckley, B.M., Buyske, S., Caspersen, I.H., Chines, P.S., Clarke, R., Claudi-Boehm, S., Cooper, M., Daw, E.W., De Jong, P.A., Deelen, J., Delgado, G., Denny, J.C., Dhonukshe-Rutten, R., Dimitriou, M., Doney, A.S., Dorr, M., Eklund, N., Eury, E., Folkersen, L., Garcia, M.E., Geller, F., Giedraitis, V., Go, A.S., Grallert, H., Grammer, T.B., Grassler, J., Gronberg, H., de Groot, L.C., Groves, C.J., Haessler, J., Hall, P., Haller, T., Hallmans, G., Hannemann, A., Hartman, C.A., Hassinen, M., Hayward, C., Heard-Costa, N.L., Helmer, Q., Hemani, G., Henders, A.K., Hillege, H.L., Hlatky, M.A., Hoffmann, W., Hoffmann, P., Holmen, O., Houwing-Duistermaat, J.J., Illig, T., Isaacs, A., James, A.L., Jeff, J., Johansen, B., Johansson, A., Jolley, J., Juliusdottir, T., Junttila, J., Kho, A.N., Kinnunen, L., Klopp, N., Kocher, T., Kratzer, W., Lichtner, P., Lind, L., Lindstrom, J., Lobbens, S., Lorentzon, M., Lu, Y., Lyssenko, V., Magnusson, P.K., Mahajan, A., Maillard, M., McArdle, W.L., McKenzie, C.A., McLachlan, S., McLaren, P.J., Menni, C., Merger, S., Milani, L., Moayyeri, A., Monda, K.L., Morken, M.A., Muller, G., Muller-Nurasyid, M., Musk, A.W., Narisu, N., Nauck, M., Nolte, I.M., Nothen, M.M., Oozageer, L., Pilz, S., Rayner, N.W., Renstrom, F., Robertson, N.R., Rose, L.M., Roussel, R., Sanna, S., Scharnagl, H., Scholtens, S., Schumacher, F.R., Schunkert, H., Scott, R.A., Sehmi, J., Seufferlein, T., Shi, J., Silventoinen, K., Smit, J.H., Smith, A.V., Smolonska, J., Stanton, 
A.V., Stirrups, K., Stott, D.J., Stringham, H.M., Sundstrom, J., Swertz, M.A., Syvanen, A.C., Tayo, B.O., Thorleifsson, G., Tyrer, J.P., van Dijk, S., van Schoor, N.M., van der Velde, N., van Heemst, D., van Oort, F.V., Vermeulen, S.H., Verweij, N., Vonk, J.M., Waite, L.L., Waldenberger, M., Wennauer, R., Wilkens, L.R., Willenborg, C., Wilsgaard, T., Wojczynski, M.K., Wong, A., Wright, A.F., Zhang, Q., Arveiler, D., Bakker, S.J., Beilby, J., Bergman, R.N., Bergmann, S., Biffar, R., Blangero, J., Boomsma, D.I., Bornstein, S.R., Bovet, P., Brambilla, P., Brown, M.J., Campbell, H., Caulfield, M.J., Chakravarti, A., Collins, R., Collins, F.S., Crawford, D.C., Cupples, L.A., Danesh, J., de Faire, U., den Ruijter, H.M., Erbel, R., Erdmann, J., Eriksson, J.G., Farrall, M., Ferrannini, E., Ferrieres, J., Ford, I., Forouhi, N.G., Forrester, T., Gansevoort, R.T., Gejman, P.V., Gieger, C., Golay, A., Gottesman, O., Gudnason, V., Gyllensten, U., Haas, D.W., Hall, A.S., Harris, T.B., Hattersley, A.T., Heath, A.C., Hengstenberg, C., Hicks, A.A., Hindorff, L.A., Hingorani, A.D., Hofman, A., Hovingh, G.K., Humphries, S.E., Hunt, S.C., Hypponen, E., Jacobs, K.B., Jarvelin, M.R., Jousilahti, P., Jula, A.M., Kaprio, J., Kastelein, J.J., Kayser, M., Kee, F., Keinanen-Kiukaanniemi, S.M., Kiemeney, L.A., Kooner, J.S., Kooperberg, C., Koskinen, S., Kovacs, P., Kraja, A.T., Kumari, M., Kuusisto, J., Lakka, T.A., Langenberg, C., Le Marchand, L., Lehtimaki, T., Lupoli, S., Madden, P.A., Mannisto, S., Manunta, P., Marette, A., Matise, T.C., McKnight, B., Meitinger, T., Moll, F.L., Montgomery, G.W., Morris, A.D., Morris, A.P., Murray, J.C., Nelis, M., Ohlsson, C., Oldehinkel, A.J., Ong, K.K., Ouwehand, W.H., Pasterkamp, G., Peters, A., Pramstaller, P.P., Price, J.F., Qi, L., Raitakari, O.T., Rankinen, T., Rao, D.C., Rice, T.K., Ritchie, M., Rudan, I., Salomaa, V., Samani, N.J., Saramies, J., Sarzynski, M.A., Schwarz, P.E., Sebert, S., Sever, P., Shuldiner, A.R., Sinisalo, J., Steinthorsdottir, V., Stolk, R.P., Tardif, J.C., Tonjes, A., Tremblay, A., Tremoli, E., Virtamo, J., Vohl, M.C., Amouyel, P., Asselbergs, F.W., Assimes, T.L., Bochud, M., Boehm, B.O., Boerwinkle, E., Bottinger, E.P., Bouchard, C., Cauchi, S., Chambers, J.C., Chanock, S.J., Cooper, R.S., de Bakker, P.I., Dedoussis, G., Ferrucci, L., Franks, P.W., Froguel, P., Groop, L.C., Haiman, C.A., Hamsten, A., Hayes, M.G., Hui, J., Hunter, D.J., Hveem, K., Jukema, J.W., Kaplan, R.C., Kivimaki, M., Kuh, D., Laakso, M., Liu, Y., Martin, N.G., Marz, W., Melbye, M., Moebus, S., Munroe, P.B., Njolstad, I., Oostra, B.A., Palmer, C.N., Pedersen, N.L., Perola, M., Perusse, L., Peters, U., Powell, J.E., Power, C., Quertermous, T., Rauramaa, R., Reinmaa, E., Ridker, P.M., Rivadeneira, F., Rotter, J.I., Saaristo, T.E., Saleheen, D., Schlessinger, D., Slagboom, P.E., Snieder, H., Spector, T.D., Strauch, K., Stumvoll, M., Tuomilehto, J., Uusitupa, M., van der Harst, P., Volzke, H., Walker, M., Wareham, N.J., Watkins, H., Wichmann, H.E., Wilson, J.F., Zanen, P., Deloukas, P., Heid, I.M., Lindgren, C.M., Mohlke, K.L., Speliotes, E.K., Thorsteinsdottir, U., Barroso, I., Fox, C.S., North, K.E., Strachan, D.P., Beckmann, J.S., Berndt, S.I., Boehnke, M., Borecki, I.B., McCarthy, M.I., Metspalu, A., Stefansson, K., Uitterlinden, A.G., van Duijn, C.M., Franke, L., Willer, C.J., Price, A.L., Lettre, G., Loos, R.J., Weedon, M.N., Ingelsson, E., O'Connell, J.R., Abecasis, G.R., Chasman, D.I., Goddard, M.E., Visscher, P.M., Hirschhorn, J.N., Frayling, T.M., 2014. Defining the role of common variation in the genomic and biological architecture of adult human height. Nat. Genet. 46, 1173-1186. 
Table 1. The association of adult height with chr1_103380393 genotype in participants used for target sequencing and replication samples.

\begin{tabular}{|c|c|c|c|c|c|c|c|}
\hline \multirow[b]{2}{*}{ Study group } & \multirow[b]{2}{*}{ Gender } & \multirow{2}{*}{$\begin{array}{l}\text { Number } \\
\text { of } \\
\text { samples }\end{array}$} & \multicolumn{3}{|c|}{ Mean height, in $\mathrm{cm}$ ( $95 \%$ c.i.) by genotype } & \multirow{2}{*}{$\begin{array}{c}\text { Per-G allele } \\
\text { effect size (s.e.m.) }\end{array}$} & \multirow[b]{2}{*}{$P$ value } \\
\hline & & & AA & AG & GG & & \\
\hline & Male & 4657 & I & $170.3(169.6,171.0)$ & $171.8(171.1,172.5)$ & $-0.268(0.053)$ & 4.80E-07 \\
\hline & Female & 3533 & l & $160.4(159.7,161.1)$ & $161.8(161.1,162.5)$ & & \\
\hline \multicolumn{8}{|l|}{ Validation in adults } \\
\hline & Male & 4358 & $169.0(168.0,169.9)$ & $169.1(168.1,170.1)$ & $171.0(170.0,171.9)$ & $-0.286(0.059)$ & $1.21 \mathrm{E}-06$ \\
\hline & Female & 4190 & l & $161.3(160.3,162.3)$ & $162.8(161.8,163.8)$ & & \\
\hline Meta-analysis in two studies & & 16738 & & & & $-0.292(0.053)$ & $3.10 \mathrm{E}-08$ \\
\hline \multicolumn{8}{|l|}{ Validation in children } \\
\hline \multirow[t]{2}{*}{$0-3 \mathrm{yrs}$} & Male & 1348 & I & $73.7(69.8,77.6)$ & $74.4(70.5,78.2)$ & $0.069(0.128)$ & 0.590 \\
\hline & Female & 618 & l & $79.9(74.6,85.4)$ & $75.8(70.5,81.2)$ & & \\
\hline $3-6 y r s$ & Female & 274 & I & $102.6(92.8,112.3)$ & $106.9(97.2,116.6)$ & & \\
\hline \multirow[t]{2}{*}{$6-9 y r s$} & Male & 269 & l & $119.2(106.9,131.5)$ & $129.8(117.5,142.1)$ & $-0.379(0.357)$ & 0.288 \\
\hline & Female & 158 & l & $121.5(102.6,140.4)$ & $125.1(106.2,144.0)$ & & \\
\hline \multirow[t]{2}{*}{$9-12 \mathrm{yrs}$} & Male & 238 & I & $148.9(143.3,154.5)$ & $146.1(140.5,151.7)$ & $0.198(0.272)$ & 0.467 \\
\hline & Female & 135 & I & $149.0(136.9,161.1)$ & $145.3(133.2,157.4)$ & & \\
\hline \multirow[t]{2}{*}{$12-15 y r s$} & Male & 184 & $145.0(138.0,151.9)$ & $156.6(149.6,163.6)$ & $162.1(155.1,169.1)$ & $-0.651(0.291)$ & 0.0258 \\
\hline & Female & 126 & I & $154.8(144.2,156.4)$ & $158.5(147.9,169.1)$ & & \\
\hline Meta-analysis in children cohorts & & 3688 & & & & $-0.018(0.09)$ & 0.843 \\
\hline
\end{tabular}

Target sequencing was performed for samples from our previous psoriasis project. Individuals $<20$ years of age were excluded in target sequencing and validation stages. Children with atopic dermatitis were $<15$ years. $P$ values are calculated using linear regression under an additive model, corrected for age and sex. Effect size (regression coefficient) and standard error of mean (s.e.m.) are expressed in standard deviation units. Meta-analysis results for adult and child cohorts are shown separately. 
Table 2. Genotype distributions and allele frequencies of chr1_103380393, rs4338381 and rs7517682 in target sequencing and validation stages

\begin{tabular}{|c|c|c|c|c|c|c|c|c|}
\hline \multirow[b]{2}{*}{ Study group } & \multirow[b]{2}{*}{ SNP } & \multirow{2}{*}{$\begin{array}{c}\text { Number } \\
\text { of } \\
\text { samples }\end{array}$} & \multicolumn{2}{|c|}{ Genotype frequency } & \multicolumn{3}{|c|}{ Allele frequency } & \multirow[b]{2}{*}{ HWE $P$-value } \\
\hline & & & $\mathbf{A}$ & B & $\mathbf{A A}$ & $\mathbf{A B}$ & BB & \\
\hline Exonic target sequencing & chr1_103380393 & & & & & & & \\
\hline Discovery set & & 8190 & $370(2.4 \%)$ & $15142(97.6 \%)$ & $0(0 \%)$ & $370(4.8 \%)$ & $7386(95.2 \%)$ & 0.024 \\
\hline Validation & chr1_103380393 & & & & & & & \\
\hline Adult & & 8548 & $293(1.7 \%)$ & $16795(98.3 \%)$ & $2(0 \%)$ & $289(3.4 \%)$ & $8253(96.6 \%)$ & 1 \\
\hline \multirow[t]{2}{*}{ Children } & & 3688 & $114(1.6 \%)$ & $7250(98.4 \%)$ & $1(0 \%)$ & $112(3 \%)$ & $3569(96.9 \%)$ & 0.590 \\
\hline & rs7517682 & & & & & & & \\
\hline Adult & & 8548 & $1580(10.2 \%)$ & $15502(89.8 \%)$ & $76(0.9 \%)$ & $1428(16.7 \%)$ & $7037(82.4 \%)$ & 0.690 \\
\hline \multirow[t]{2}{*}{ Children } & & 3688 & $697(10.4 \%)$ & $6679(89.6 \%)$ & $26(0.7 \%)$ & $645(17.5 \%)$ & $3017(81.8 \%)$ & 0.210 \\
\hline & rs 4338381 & & & & & & & \\
\hline Adult & & 8548 & $448(2.7 \%)$ & $16224(97.3 \%)$ & $0(0 \%)$ & $448(5.4 \%)$ & $7888(94.6 \%)$ & 0.048 \\
\hline Children & & 3688 & $178(3.2 \%)$ & $6678(96.8 \%)$ & $0(0 \%)$ & $178(5.2 \%)$ & $3250(94.8 \%)$ & 0.170 \\
\hline
\end{tabular}

